\title{
Establishment and function of tissue-resident innate lymphoid cells in the skin
}

\author{
Jie Yang ${ }^{1,2}$, Luming Zhao ${ }^{1}$, Ming $\mathrm{Xu}^{1}$, Na Xiong ${ }^{1 凶}$ \\ ${ }^{1}$ Centre for Molecular Immunology and Infectious Diseases and Department of Veterinary and Biomedical Sciences, \\ The Pennsylvania State University, University Park, PA 16802, USA \\ 2 Department of Immunology, The University of Texas MD Anderson Cancer Center, 7455 Fannin Street, \\ Houston, TX 77054, USA \\ $\bowtie$ Correspondence: nux1@psu.edu (N. Xiong) \\ Received January 1, 2017 Accepted February 15, 2017
}

\begin{abstract}
Innate lymphoid cells (ILCs) are a newly classified family of immune cells of the lymphoid lineage. While they could be found in both lymphoid organs and non-lymphoid tissues, ILCs are preferentially enriched in barrier tissues such as the skin, intestine, and lung where they could play important roles in maintenance of tissue integrity and function and protection against assaults of foreign agents. On the other hand, dysregulated activation of ILCs could contribute to tissue inflammatory diseases. In spite of recent progress towards understanding roles of ILCs in the health and disease, mechanisms regulating specific establishment, activation, and function of ILCs in barrier tissues are still poorly understood. We herein review the up-to-date understanding of tissue-specific relevance of ILCs. Particularly we will focus on resident ILCs of the skin, the outmost barrier tissue critical in protection against various foreign hazardous agents and maintenance of thermal and water balance. In addition, we will discuss remaining outstanding questions yet to be addressed.
\end{abstract}

KEYWORDS innate lymphoid cells, skin, migration, chemokine receptor, homeostasis, inflammation

\section{INTRODUCTION}

Innate lymphoid cells (ILCs) are the newly identified members of the innate immune system. ILCs have the property of classic lymphoid cells but lack rearranged antigen-specific receptors (Spits et al., 2013; Walker et al., 2013). ILCs encompass conventional natural killer (NK) cells and lymphoid tissue inducer (LTi) cells, which were first discovered in 1975 and 1997, respectively (Kiessling et al., 1975a; Kiessling et al., 1975b; Mebius et al., 1997), and other recently described subsets. ILCs can be generally identified by their expression of certain subunits of cytokine receptors such as CD25 (interleukin (IL)-2 receptor $\alpha$ ) and CD127 (IL-7 receptor $\alpha$ ) but no cell-surface molecules that identify the other types of immune cells (lineage marker-negative or $\mathrm{Lin}^{-}$) (Artis and Spits, 2015). While ILCs could be found in nearly every tissue and organ, they are preferentially enriched in barrier tissues such as the skin, intestine and lung, where they participate in local tissue homeostasis and inflammation (Artis and Spits, 2015; McKenzie et al., 2014).

\section{SUBSETS OF INNATE LYMPHOID CELLS}

In analog to helper T (Th) cells, ILCs are conventionally divided into three groups based on their differential expression of effector cytokines and developmental requirements for transcription factors (Spits et al., 2013). The group 1 ILCs are composed of ILCs capable of producing interferon $\mathrm{Y}$ (IFNY), which include NK cells and non-cytotoxic helper-like ILC1s. NK cells are innate effector lymphocytes that are capable of inducing granule-mediated cytotoxicity by expressing perforin and granzymes, as well as producing IFNy and tumor necrosis factor $\alpha$ (TNFa) (Herberman et al., 1975a; Herberman et al., 1975b; Kiessling et al., 1975a; Kiessling et al., 1975b; Vivier et al., 2011). On the other hand, non-cytotoxic ILC1s are innate helper lymphocytes that are capable of producing IFNy, TNF $\alpha$ and other Th1-associated cytokines, but lack cytotoxic abilities (Artis and Spits, 2015; Bernink et al., 2013; Vonarbourg et al., 2010). Recent studies identified additional developmental and phenotypic differences between NK and ILC1s (Constantinides et al., 2014; 
Klose et al., 2014). While eomesodermin (Eomes) is required for development of NK cells, T-bet and GATA3 are critical for ILC1s (Daussy et al., 2014; Gordon et al., 2012; Yagi et al., 2014). In addition, NK cells re-circulate in the blood while ILC1s predominantly reside in tissues (Sojka et al., 2014). Group 2 ILCs produce Th2-associated cytokines such as IL-4, IL-5, and IL-13 when activated, and depend on GATA3 and RORa for their development (Halim et al., 2012; Hoyler et al., 2012). Group 3 ILCs are highly heterogeneous, although they preferentially produce Th17-assciated cytokines including IL-17A and IL-22 and require RORyt for the development. Based on their expression of the chemokine receptor CCR6, group 3 ILCs can be divided into two subsets (Klose et al., 2013; Sawa et al., 2011). CCR6 ${ }^{+}$ILC3s consist of $\mathrm{CD}^{+}$and $\mathrm{CD}^{-}{ }^{-} \mathrm{LTi}$ cells, while CCR6 ${ }^{-}$ILC3s are composed of two subpopulations that have distinct expression of the natural cytotoxicity receptor (NCR) NKp46 (Klose et al., 2013; Rankin et al., 2013).

ILCs of the different groups can show certain functional plasticity. For example, in response to IL-12 and IL-18, $\mathrm{CCR}^{-} \mathrm{NKp}^{-} 6^{-}$ILC3s increase expression of T-bet and differentiate into $\mathrm{CCR}^{-} \mathrm{NKp}^{+} 6^{+}$ILC3s, which can further increase T-bet and decrease RORyt expression and differentiate into ex-RORyt ${ }^{+}$ILC3s that display ILC1-like functions with increased production of IFNy and decreased IL-17A and IL-22 (Artis and Spits, 2015; Bernink et al., 2013; Cella et al., 2010; Klose et al., 2013; Vonarbourg et al., 2010). Using the single cell transcription analysis, a recent study found that there are significant heterogeneities within ILCs and that some of them display transcription profiles associated with more than one group of ILCs, consistent with the notion that they are of transition stages (Gury-BenAri et al., 2016).

\section{DEVELOPMENT OF INNATE LYMPHOID CELLS}

Common lymphoid progenitor cells of the bone marrow give rise to all lymphocytes, including ILCs. Several intermediate progenitors have been identified that have the potential to give rise to different subsets of ILCs. Committed ILC precursors can differentiate into all ILC subsets, including NK cells, but not T and B cells (Seillet et al., 2014; Yu et al., 2014). They are termed $\alpha$-lymphoid precursor ( $\alpha$ LP) cells because they express the integrin $\alpha 4 \beta 7$, but also known as common innate lymphoid progenitor (CILP). aLP cells express the chemokine receptor CXCR6 and require the transcription factor NFIL3 for development (Seillet et al., 2014; Yu et al., 2014). Downstream of $\alpha$ LP, two populations of ILC precursor cells have been identified based on the expression of inhibitor of DNA binding 2 (Id2) and promyeloid leukemia zinc finger (PLZF) (Constantinides et al., 2014; Klose et al., 2014). Common helper-like innate lymphoid progenitor (CHILP) cells are $\mathrm{Id} 2^{+} \mathrm{Lin}^{-} \mathrm{IL}-7 \mathrm{Ra}^{+} \alpha 4 \beta 7^{+} \mathrm{CD} 25^{-}$ and dependent on GATA3 for development. CHILP can give rise to non-cytotoxic ILC1s, ILC2s and ILC3s, but no NK cells (Klose et al., 2014). Innate lymphoid progenitor (ILCP) cells are PLZF ${ }^{\text {high }}$ Lin $^{-}$IL-7Ra ${ }^{+} \mathrm{CKit}^{+} \alpha 4 \beta 7^{\text {high }} \mathrm{CXCR6}^{-}$. ILCP differentiates efficiently into the majority of ILC subsets except NK cells and LTi cells (Constantinides et al., 2014). ILCP is thus placed downstream of CHILP because ILCP has a more restricted differentiation potential than CHILP. More recently, a population of the transcription factor TCF- $1^{+}$ early ILC progenitor (EILP) cells were also described (Yang et al., 2015). The TCF-1 ${ }^{+}$EILP cells are IL-7Ra ${ }^{\text {neg/low- }}$ Thy 1 Lin $^{-} \mathrm{CD} 122^{-} \mathrm{CXCR}^{-}$and express low levels of PLZF. EILP could develop into all subsets of ILCs, including conventional NK cells, but not T/B cells (Yang et al., 2015). TCF-1 knockout mice have reduced EILP as well as NKP and CHILP, suggesting that TCF-1 is critical for development of EILP and that NKP and CHILP are downstream of EILP (Yang et al., 2015). The relationship between EILP and aLP is not fully characterized even though EILP seems to functionally overlap with aLP in their ability to differentiate into ILCs but not T/B cells. Detailed developmental pathway and regulation of the ILC differentiation have been extensively reviewed (Ishizuka et al., 2016; Serafini et al., 2015; Yang and Bhandoola, 2016; Zook and Kee, 2016).

\section{FUNCTION OF INNATE LYMPHOID CELLS IN MAINTENANCE OF TISSUE HOMEOSTASIS AND HOST PROTECTION}

ILCs are enriched in barrier tissues where they play important roles in maintenance of tissue homeostasis, regulation of equilibrium between the host and microbiota, and immunity against pathogens (Artis and Spits, 2015; McKenzie et al., 2014; Walker et al., 2013). In addition, ILCs participate in the development of lymphoid tissues, tissue remodeling, and metabolic homeostasis (Artis and Spits, 2015; McKenzie et al., 2014; Walker et al., 2013).

Functions of NK cells of the group 1 ILC family have been well established, which include killing virus-infected cells through cytolysis mediated by granzymes and perforin, and targeting tumor cells that have lost expression of the class I major histocompatibility complex $(\mathrm{MHCl})$ (Biron et al., 1999; Vivier et al., 2012). The other non-cytotoxic ILC1s can produce high amounts of IFNy and TNFa, contributing to the protection of hosts against bacteria and intracellular parasites (Klose et al., 2014; Klose et al., 2013). More recently, it was also reported that ILC1s play an important role in the early protection against tumor genesis (Dadi et al., 2016).

ILC2s are a critical innate source of type 2 cytokines, such as IL-4, IL-5, IL-9 and IL-13, which can induce eosinophilia, mastocytosis, activation of alternatively activated macrophages, goblet cell hyperplasia and muscle contractility, and tissue repair (Pulendran and Artis, 2012). ILC2s can be activated by cytokines such as IL-25, IL-33, and thymic stromal lymphopoietin (TSLP) (Hams et al., 2014; Kim et al., 2013; McHedlidze et al., 2013). During parasitic helminth infection, ILC2s are identified as an important source of IL-13 critical for the parasite expulsion (Moro et al., 2016; Neill et al., 2010; Price et al., 2010). ILC2s 
also express amphiregulin and are involved in tissue repairing after virus infection (Monticelli et al., 2011). In addition, growing evidence demonstrates roles of ILC2s in metabolic homeostasis (Hams et al., 2013; Molofsky et al., 2013; Stanya et al., 2013). ILC2s in visceral adipose tissue produce IL-5 and IL-13 and maintain responses of eosinophil and alternatively activated macrophages, lack of which results in increased adiposity and insulin resistance (Molofsky et al., 2013). ILCs can respond to changes in nutrients such as Vitamin A, deficiency of which leads to reduced ILC3s but increased ILC2s in intestines and is associated with defective antibacterial immunity but enhanced anti-helminth immunity (Spencer et al., 2014). Circadian clock also regulates cytokine production of intestinal ILC2s through vasoactive intestinal peptides (Nussbaum et al., 2013).

The role of LTi cells of the group 3 ILCs family in the development of lymphoid organs of lymph nodes (LNs) and Peyer's patches has long been recognized (De Togni et al., 1994; Eberl et al., 2004). Lymphotoxin $\alpha 1 \beta 2$ produced by LTi cells binds to lymphotoxin $\beta$ receptor on stromal cells to induce the production of chemokines and upregulation of adhesion molecules, which recruit leukocytes to form lymphoid structures (van de Pavert et al., 2009). ILC3s have also been implicated in tissue repair following inflammation or damage in multiple tissues, including intestines, thymi, and lungs (Dudakov et al., 2012; Sawa et al., 2011; Taube et al., 2011). ILC3s are an important source of IL-22, which promotes epithelial cells to express antimicrobial peptides to protect against pathogens (Sonnenberg et al., 2011; Zheng et al., 2008). In addition, ILC3s interact with stromal cells and other immune cells to maintain balance between the host and microbiota by limiting dissemination of commensal bacteria and inappropriate immune responses to them (Sonnenberg et al., 2012).

\section{PARTICIPATION OF INNATE LYMPHOID CELLS IN PATHOGENESIS OF DISEASES}

Although ILCs normally play host-protective roles, dysregulated activation of ILCs could lead to inflammatory diseases (Artis and Spits, 2015; McKenzie et al., 2014; Walker et al., 2013). IFNy-producing ILCs, including ILC1s and ex-RORyt ${ }^{+}$ ILC3s, can induce inflammation in the intestines of both mice and humans (Bernink et al., 2013; Buonocore et al., 2010; Fuchs et al., 2013). In the adipose tissue, high fat diet could activate ILC1s to produce IFNy and promote inflammatory macrophage polarization and development of insulin resistance (O'Sullivan et al., 2016).

Chronic ILC2 activation was reported to contribute to a large variety of tissue inflammatory disorders such as asthma in the lung and atopic dermatitis in the skin, which are generally associated with over-production of the type 2 inflammatory cytokines such as IL-4, IL-5, and IL-13. ILC2s expand and produce the type 2 cytokines in mice with allergic lung inflammation (Chang et al., 2011; Halim et al., 2014), consistent with the increase of ILC2s in peripheral blood of patients with asthma (Bartemes et al., 2014; Moffatt et al., 2010). Increased frequency of ILC2s was found in lesional skin of mouse models and human patients with atopic dermatitis (Imai et al., 2013; Kim et al., 2013; Salimi et al., 2013).

ILC3s could contribute to inflammatory diseases and tumorigenesis in various tissues. IL-17- and IL-22-producing ILC3s have been linked with the inflammatory skin disease psoriasis, inflammatory bowl disease, obesity-associated asthma, and multiple sclerosis (Buonocore et al., 2010; Kim et al., 2014b; Pantelyushin et al., 2012; Perry et al., 2012; Powell et al., 2012; Teunissen et al., 2014; Villanova et al., 2014). IL-22 produced by ILC3s can contribute to development of colon cancer in a mouse model, consistent with the presence of IL-22-producing $\mathrm{CD}^{-}$cells within human colorectal carcinoma tumors (Kirchberger et al., 2013).

\section{INNATE LYMPHOID CELLS ARE PREDOMINANTLY TISSUE-RESIDENT CELLS}

Specific functions of ILCs in homeostasis and inflammation are associated with their unique localization in peripheral tissues. Recently, several groups reported that ILCs are predominantly tissue-resident cells that do not circulate in the body. In parabiotic studies, helper-like ILCs in both nonlymphoid tissues and lymphoid organs such as the small intestine, salivary gland, lung, mensenteric lymph node, and adipose tissue of two joined adult mice with shared blood circulation systems remain locally and do not move from one mouse to another (Gasteiger et al., 2015; O'Sullivan et al., 2016). However, conventional NK cells are mostly circulating cells (Peng et al., 2013; Sojka et al., 2014). Furthermore, systemic inflammation or infection did not mobilize tissueresident ILCs into the circulation either (Gasteiger et al., 2015). These suggest that ILCs or their progenitor cells might settle in specific peripheral tissues at early ontogenic stages and are maintained and expanded locally. Consistent with this notion, progenitor cells of ILCs have been identified in lymph nodes of humans that could give rise to all innate lymphoid cells in the in vitro development analysis (Scoville et al., 2016). In addition, the bone marrow reconstitution in human patients with severe combined immunodeficiency (SCID) due to mutation of the gene encoding the common $y$ chain cytokine receptor subunit IL-2RY or the tyrosine kinase JAK3 did not restore presence of ILCs in various peripheral tissues (Vely et al., 2016), supporting the notion that tissueresident ILCs are established at early ontogenic stages. Mechanisms regulating specific localization and maintenance of ILCs in various peripheral tissues are still poorly understood.

\section{MIGRATION AND ESTABLISHMENT OF INNATE LYMPHOID CELLS IN THE SKIN}

Skin is the outmost barrier tissue constantly exposed to assaults of various foreign agents. Skin is enriched with ILCs 
and ILCs of all the three groups could be found in the skin (Yang et al., 2016). Based on expression of the transcription factor GATA3 and the cytokines such as IL-4 and IL-5, ILC2s account for a major fraction of total skin ILCs in adult mice (Roediger et al., 2013; Yang et al., 2016). Although few ILCs of the skin in mice express the transcription factor RORyt, a significant fraction of skin ILCs are capable of producing IL-17A, suggesting that they are ILC3s or ILC3-like cells independent of RORyt (Yang et al., 2016). However, their lineage relationship with other RORyt-expressing ILC3s is not known. The group 1 ILCs, including NK cells, are present in the skin of mice (Luci et al., 2009; Yang et al., 2016), and they account for a smaller fraction of total skin ILCs than ILC2s or ILC3s in adult mice (Yang et al., 2016). On the other hand, in the skin of fetal and newborn mice, there are abundant NK1.1 $1^{+}$ILC1-type cells although their origin and lineage association are not known (Almeida et al., 2015). As in mice, ILCs of all the three groups are found in the healthy skin of humans (Dyring-Andersen et al., 2014; Ebert et al., 2006; Salimi et al., 2013; Teunissen et al., 2014; Villanova et al., 2014). Based on their expression of the prostaglandin D2 receptor CRTH2, ILC2s account for $25 \%-40 \%$ of skin ILCs in humans (Dyring-Andersen et al., 2014; Salimi et al., 2013; Teunissen et al., 2014; Villanova et al., 2014). ILC3s, including both $\mathrm{NCR}^{+}$and $\mathrm{NCR}^{-}$subsets, account for about $50 \%$ of total skin ILCs in humans (Dyring-Andersen et al., 2014; Teunissen et al., 2014; Villanova et al., 2014). The rest are ILC1s and others uncharacterized.

Since ILCs share many common regulatory pathways with helper $\mathrm{T}$ cells for their development and function, we investigated whether skin-specific ILCs are programmed in skin-draining lymph nodes to acquire their skin-homing property for establishment of their skin residency, paralleling the process by which the skin-homing property of conventional $\alpha \beta T$ cells is imprinted in skin-draining lymph nodes (Yang et al., 2016). Among the most skin-specific homing molecules expressed on skin-homing T cells and ILCs is the chemokine receptor CCR10 (Sigmundsdottir and Butcher, 2008; Sigmundsdottir et al., 2007; Xiong et al., 2012; Yang et al., 2016). A ligand for CCR10, CCL27, is highly and specifically expressed by keratinocytes of the healthy skin in both humans and mice (Homey et al., 2000; Morales et al., 1999). The adhesion molecules E- and P-selectin ligands and chemokine receptors CCR4, CCR6, and CCR8 are also involved in the skin-homing process in the healthy skin (Austrup et al., 1997; Campbell and Butcher, 2002; Campbell et al., 1999; Picker et al., 1993; Reiss et al., 2001; Weninger et al., 2000). In addition, different sets of homing molecules are involved in migration of immune cells to the inflamed skin under specific inflammatory conditions than those under homeostatic conditions (Lonsdorf et al., 2009; Masopust and Schenkel, 2013; Mora and von Andrian, 2006). For example, high induction of the chemokines CCL1 and CCL18 is found in the lesional skin of patients with atopic dermatitis (Gombert et al., 2005; Pivarcsi et al., 2004). The chemokine receptor CXCR3 is involved in migration of $\mathrm{T}$ cells to the inflamed skin, where its ligands CXCL9, CXCL10, and CXCL11 are produced (Flier et al., 2001). While CCL27 could be upregulated in the skin under inflammatory conditions of allergic contact dermatitis, atopic dermatitis, and psoriasis (Homey et al., 2002; Moed et al., 2004), it is profoundly suppressed in severe psoriatic skin lesions (Gudjonsson et al., 2010; Quaranta et al., 2014; Riis et al., 2011a). In the same patient, CCL27 expression is much lower in psoriatic lesional skin than in peri-lesional skin (Karakawa et al., 2014; Riis et al., 2011a), suggesting that its expression is associated with severity of the disease. Indeed, CCL27 is upregulated in the skin by the inflammatory cytokines TNF $\alpha$ and IL-1 $\beta$ at the early phase of inflammation (Riis et al., 2011b; Vestergaard et al., 2004) but is suppressed by pathognomonic cytokines such as IL-17A and IFNy at the late, severe stage of skin inflammation (Kanda et al., 2005; Karakawa et al., 2014). We recently found that CCR10 is critical for migration of T cells into the skin under steady-state conditions but is dispensable for their infiltration into inflamed skin (Fu et al., 2016; Xia et al., 2014). Like T cells, ILCs are also programmed in skindraining lymph nodes to acquire the CCR10 expression for their migration to the skin under steady-state conditions (Yang et al., 2016). In CCR10-knockout mice, ILCs generated in skin-draining lymph nodes is defective in migration into the skin and increasingly diverted into spleens and other sites where CCR10 ligands are not expressed (Yang et al., 2016). Moreover, skin-specific $C D 207^{+}$dendritic cells are involved in the programming of skin-homing CCR $10^{+}$ILCs in skin-draining lymph nodes (Yang et al., 2016) (Fig. 1).

Dependent on environmental cues of lymphoid organs in which T cells and ILCs are activated, they could be also imprinted to acquire homing properties to other distinct peripheral tissues (Campbell and Butcher, 2002; Kantele et al., 1999; Masopust and Schenkel, 2013; Mora et al., 2003; Mora et al., 2005; Mora and von Andrian, 2006; Rott et al., 1997; Weninger et al., 2000). A recent study reported that ILCs undergo a homing receptor switch by upregulation of CCR9 and $\alpha 4 \beta 7$ and downregulation of CCR7 in intestinedraining mesenteric lymph nodes in a retinoic acid-dependent manner for their migration into the intestine (Kim et al., 2015). Together with the findings in the skin, these results suggest that specific epithelial tissues and their associated lymph nodes form an integral unit for generation and maintenance of tissue-specific ILCs. However, there might be other regulatory mechanisms in establishment of tissuespecific ILCs (Kim et al., 2015; Yang et al., 2016). In our study of the generation of skin-specific CCR10 ${ }^{+}$ILCs in skindraining lymph nodes, local inflammatory conditions suppress programming of skin-homing $\mathrm{CCR} 10^{+}$ILCs (Yang et al., 2016) (Fig. 1). Molecular factors regulating the distinctive generation and establishment of skin-specific ILCs under homeostatic and inflammatory conditions are mostly unknown. 


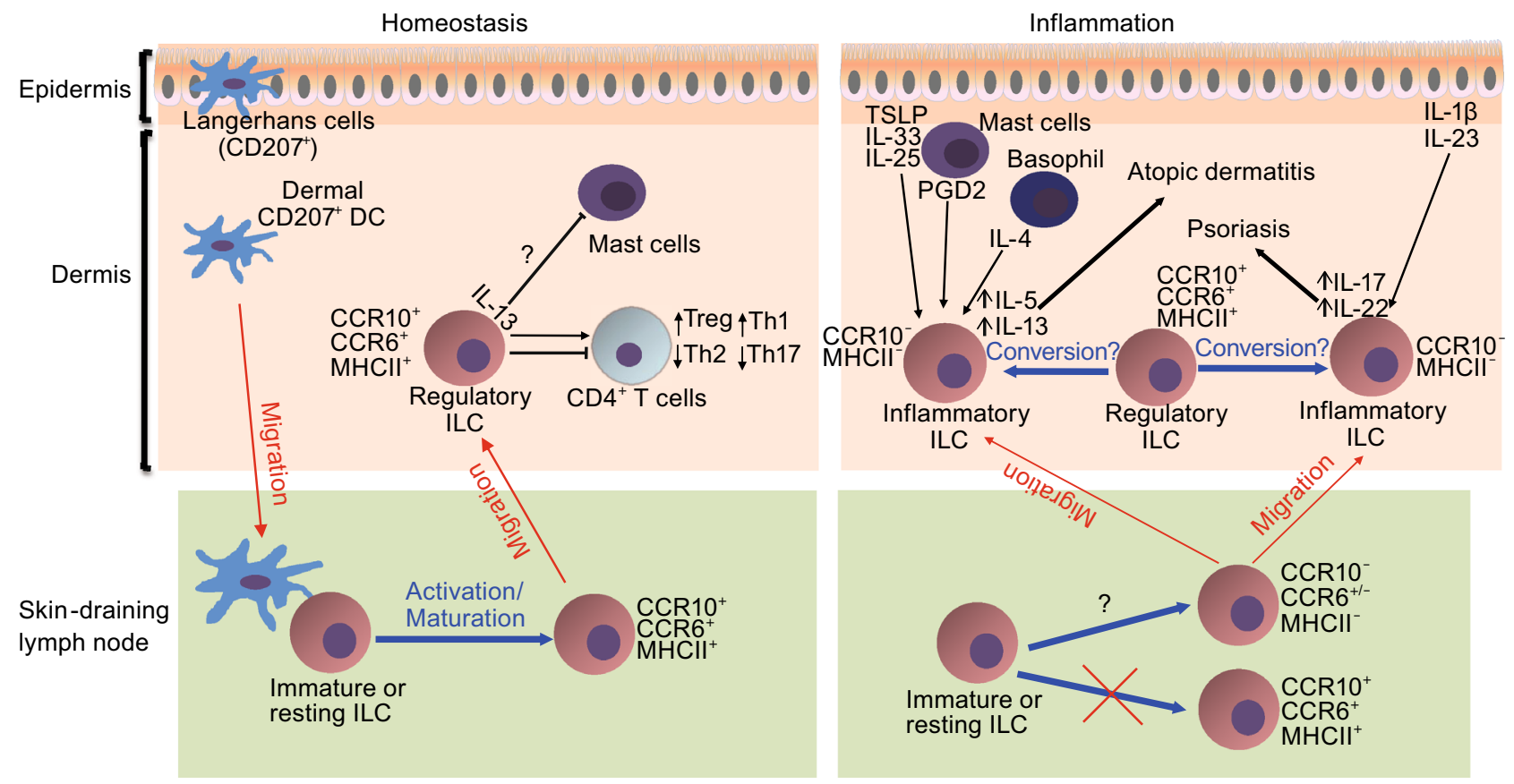

Figure 1. Schematic illustration of establishment and function of ILCs in the skin homeostasis and inflammation. Under homeostatic conditions, CCR $10^{+}$ILCs with regulatory properties are preferentially generated in skin-draining lymph nodes and migrate into the skin where they promote the local immune homeostasis by controlling balanced presence and activation of other immune cells. Under inflammatory conditions, there is reduced generation of CCR $10^{+}$regulatory ILCs in skin-draining lymph nodes. In addition, there is also increased conversion of regulatory CCR $10^{+}$ILCs to inflammatory CCR $10^{-}$ILCs, which promote immune activation and inflammatory processes in diseases such as atopic dermatitis and psoriasis, depending cytokines produced by the activated inflammatory ILCs.

\section{INTERACTION BETWEEN INNATE LYMPHOID CELLS AND LOCAL IMMUNE AND NON-IMMUNE CELLS IN PARTICIPATION OF SKIN INFLAMMATION}

Compared to the healthy skin, ILC2s are increased in the skin of patients with atopic dermatitis (Kim et al., 2013; Salimi et al., 2013), suggesting that ILC2s are involved in atopic dermatitis, an inflammatory disease associated with over-active type 2 immune responses to environmental allergens and barrier dysfunction (Leung, 2013). In a mouse model of atopic dermatitis induced by topical application of Calcipotriene (a synthetic Vitamin D3 derivative), ILC2derived IL-5 and IL-13 were reported to play an important role in promoting the disease development (Kim et al., 2013) (Fig. 1). It was also found that skin ILC2s are activated by TSLP produced by skin keratinocytes in response to the topical Calcipotriene-treatment (Kim et al., 2013). Another study identified the role of IL-33 and IL-25 in activating skin ILC2s to promote atopic dermatitis (Salimi et al., 2013). Consistent with this, transgenic overexpression of IL-33 in keratinocytes promotes accumulation of ILC2s in the skin and induces atopic dermatitis-like disease (Imai et al., 2013). Prostaglandin D2 (PGD2), acting through its receptor CRTH2 expressed on human skin ILC2s, induces migration and cytokine production of ILC2s in human atopic dermatitis skin (Xue et al., 2014). Mast cells could be an important source of prostaglandin D2 for activation of ILC2s (Barnig et al., 2013; Roediger et al., 2013). IL-4 derived from basophils was also shown to regulate the proliferation of skin ILC2s, which express the IL-4 receptor IL-4Ra, and induce atopic dermatitis-like disease (Kim et al., 2014a). Given the role of E-cadherin in inhibiting the cytokine production of ILC2s via binding to the inhibitory receptor KLRG1 expressed on skin ILC2s, downregulation of E-cadherin in atopic dermatitis skin might also contribute to the activation of skin ILC2s (Salimi et al., 2013).

Increasing evidence implicates involvement of ILC3s in psoriasis, a skin inflammatory disease largely resulting from overproduction of Th17-associated cytokines such as IL-17A (Dyring-Andersen et al., 2014; Pantelyushin et al., 2012; Teunissen et al., 2014; Villanova et al., 2014). In a mouse model of psoriasis induced by topical application of Imiquimod, it was found that ILC3s are a cellular source of IL-17A and IL-22 that mediate the Imiquimod-induced psoriasis-like disease (Pantelyushin et al., 2012). In patients with psoriasis, NKp44 ${ }^{+}$ILC3s are increased in both lesional and nonlesional skin and NKp44- ILC3s have the potential to differentiate to $\mathrm{NKp} 44^{+}$ILC3s in response to stimulation of 
IL-1 $\beta$ and IL-23 (Teunissen et al., 2014; Villanova et al., 2014). Increased percentages of $\mathrm{NKG}^{2} \mathrm{D}^{+} \mathrm{RORyt}^{+} \mathrm{CD} 56^{+}$ ILC3s were found in the psoriatic skin in a separate study (Dyring-Andersen et al., 2014). There is a positive correlation between reduction of ILC3s and therapeutic response in psoriatic patients treated with anti-TNFa antibody (Villanova et al., 2014), supporting involvement of ILC3s in psoriasis. Cellular and molecular factors promoting activation of ILC3s in participation of psoriasis are still not well understood but could involve cytokines produced by myeloid, lymphoid, epithelial, and stromal cells of the skin (Gasteiger and Rudensky, 2014) (Fig. 1).

\section{CROSSTALK BETWEEN INNATE LYMPHOID CELLS AND OTHER SKIN IMMUNE CELLS IN MAINTENANCE OF LOCAL TISSUE HOMEOSTASIS AND HOST PROTECTION}

While ILCs are relatively well studied for their participation in development of skin inflammatory diseases, their physiological role in maintenance of the skin homeostasis and host protection is still poorly understood. Since ILC2s are capable of producing amphiregulin, a member of epithelial growth factor family, they could potentially contribute to wound healing (Salimi et al., 2013). Similarly, IL-22 produced by ILC3s is an important growth factor of keratinocytes. Indeed, both ILC2s and ILC3s were recently reported to promote the wound healing process in mouse models (Li et al., 2016; Rak et al., 2016). The ILC2 response is promoted by the cutaneous injury in an IL-33-dependent manner (Rak et al., 2016), while ILC3s are recruited into wounded dermis by epidermal Notch1, which functions as a damage response signal (Li et al., 2016).

Skin ILCs interact with other skin-resident immune cells to maintain the immune homeostatic condition. In the steadystate skin, the preferential interaction of ILC2s and mast cells has been detected (Barnig et al., 2013; Roediger et al., 2013). IL-13 produced by skin ILC2s suppresses the function of mast cells in homeostatic conditions, suggesting a regulatory role of skin ILC2s (Roediger et al., 2013). ILCs might also interact with $\mathrm{T}$ cells to regulate their homeostasis in the skin (Yang et al., 2016), as reported in recent studies on the cross-regulation between ILCs and T cells in several other barrier tissues. ILC2s express MHCII and activate T cells to induce production of IL-2, which in turn promote the proliferation of ILC2s and their expression of type 2 cytokines for worm expulsion in the gut (Oliphant et al., 2014). In a model of allergic lung inflammation, IL-13 produced by ILC2s promotes the migration of dendritic cells to draining lymph nodes where they prime T cells to differentiate into Th2 cells (Halim et al., 2014). The co-stimulatory molecule OX40L and ILC2-derived IL-4 were reportedly involved in crosstalk between ILC2s and T cells (Drake et al., 2014). Intestinal MHCII-expressing ILC3s have the capacity to present antigens to $\mathrm{CD}^{+}{ }^{+} \mathrm{T}$ cells and dampen their responses to microbiota (Hepworth et al., 2013). In addition, intestinal microbiota induces the production of GM-CSF by ILC3s, which promotes macrophages to produce retinoic acid and results in a tolerogenic state through enhancing function of regulatory T cells (Mortha et al., 2014). ILC3s could regulate the gut flora to control intestinal homeostasis and protect the host from intestinal pathogen infection (Goto et al., 2014; Guo et al., 2015; Qu et al., 2013). Intestinal ILC3s also promote the immunoglobulin $\mathrm{A}$ antibody production by $\mathrm{B}$ cells through membrane lymphotoxin $\alpha 1 \beta 2$ (Kruglov et al., 2013). In our study of skin ILCs, we found that interaction between skin-specific CCR $10^{+}$ILCs and T cells plays a critical role in maintaining the immune homeostasis of the skin (Yang et al., 2016). In Rag1 $1^{-/-}$mice that lack T and B cells, there are significantly reduced CCR $10^{+}$ILCs in the skin, while transfer of $\mathrm{CD}^{+} \mathrm{T}$ cells could partially restore the homeostatic presence of CCR10 ${ }^{+}$ILCs (Yang et al., 2016). Reciprocally, ILCs regulate homeostasis of resident T cells in the skin. When transferred into $I / 2 \mathrm{rg}^{-/-} \mathrm{Rag}^{-/-}$mice, which lack all ILCs as well as T/B cells, donor $\mathrm{CD}^{+}{ }^{+} \mathrm{T}$ cells in skin of hosts contain significantly higher percentages of IL-17Aproducing Th17 and IL-5-producing Th2 cells but much lower percentages of IFNY-producing Th1 cells than those transferred into $R a g 1^{-1-}$ recipients that have ILCs (Yang et al., 2016). In absence of ILCs, there are also significantly reduced presence of regulatory $T$ cells in the skin, indicating an important role of ILCs in regulating the homeostasis of skin T cells (Yang et al., 2016) (Fig. 1).

\section{PERSPECTIVES}

The research over past several years has started to reveal roles of ILCs in the skin and unravel mechanisms regulating establishment and function of the skin-resident ILCs. However, several major questions remain to be addressed. First, physiological functions of skin-resident ILCs in host protection and immune homeostatic maintenance are still poorly understood. While ILCs have been generally implicated in protection against infection, control of commensal bacteria and regulation of immune activation in various barrier tissues, the function of resident ILCs specifically in the skin is not well studied. Considering that ILCs are maintained locally in different barrier tissues, functions and regulation of ILCs in the skin and other barrier tissues are likely regulated differently with local environmental cues. For example, the CCR10/ CCL27 axis is involved in the regulation of resident ILCs in the skin but not other sites (Yang et al., 2016). Further studies are needed to understand how tissue-specific factors are involved in regulation and function of skin-specific ILCs. Associated with this, molecular mechanisms regulating tissue-specific establishment of ILCs in the skin versus other barrier tissues need further investigation. Furthermore, functions of different groups of ILCs in the skin require delineation at different ontogenic stages. For example, although group $1 \mathrm{ILCs}$, including conventional NK cells, are abundantly present in the skin of both humans and mice, particularly in the newborn and 
young (Batista et al., 2013; Ebert et al., 2006; Luci et al., 2009; Teunissen et al., 2014; Villanova et al., 2014), their roles in establishment of skin homeostasis are mostly unknown and need further investigation.

Second, mechanisms regulating differential involvement of ILCs in the skin homeostasis and inflammation are largely unknown. Studies of ILCs of the skin and other barrier tissues have showed that ILCs could be involved in both homeostatic regulation and tissue inflammatory processes. However, it is currently unknown whether and how ILCs involved in homeostatic regulation are different from ILCs involved in immune inflammatory processes in the skin. Our studies have found that CCR $10^{+}$ILCs are dominant in the healthy skin where they promote balanced maintenance of resident T cells (Yang et al., 2016). In immune dysregulatory or inflammatory conditions of $\mathrm{Rag}^{-/-}$, Foxp3 $3^{-/-}$or topical Calcipotriol-treated wild-type mice, CCR10 ${ }^{+}$ILCs are decreased while CCR10 ${ }^{-}$ILCs are increased in the skin (Yang et al., 2016), suggesting that $\mathrm{CCR}^{+}$and CCR10 ILCs might be differently involved in skin immune homeostatic regulation and activation (Fig. 1). Further study on how CCR $10^{+}$and CCR $10^{-}$skin ILCs are regulated and function should help understand basic biology of the skin-specific ILCs in the health and disease.

Third, the involvement of ILCs in promoting diseases has raised interest in modulating ILC functions for the treatment of diseases. In other tissues, antibodies against ILC2-activating cytokines, such as IL-25 and IL-33, as well as those targeting ILC2-produced cytokines, including IL-5 and IL-13, have been found to suppress ILC2 proliferation and function in tissue inflammatory diseases in the lung (Gauvreau et al., 2014; Hambly and Nair, 2014). Blockage of the binding of prostaglandin D2 to CRTH2 expressed on human ILC2s inhibits the migration and cytokine production of ILC2s (Barnig et al., 2013; Xue et al., 2014). Montelukast, a leukotriene receptor antagonist, inhibits the cytokine production of ILC2s by blocking interaction between leukotriene D4 and cysteinyl leukotriene receptor 1 (CysLT1R) expressed by ILC2s (Doherty et al., 2013). ILC3s have been targeted in the treatment of multiple sclerosis by anti-IL-2R antibody (Perry et al., 2012). Antagonists of RORyt, which can regulate the activity of Th17, might also target ILC3s (Bernink et al., 2015; Solt et al., 2011; Withers et al., 2016). However, while there is a report showing that inhibition of RORyt reduces differentiation of CD127 $7^{+}$ILC1s to ILC3s (Bernink et al., 2015), inhibition of RORyt does not impair function of mature ILC3s (Bernink et al., 2015; Withers et al., 2016). How to target ILCs in the skin to modulate their cytokine production for treatment of skin inflammatory diseases is still understudied and might represent a new area of study for disease treatment.

\section{ACKNOWLEDGEMENTS}

Research reported in this publication was partly supported by the National Institute of Allergy and Infectious Diseases and the National
Institute of Arthritis and Musculoskeletal and Skin Diseases of the National Institutes of Health under Award Numbers AR064831 and Al071043 (to N.X). The content is solely the responsibility of the authors and does not necessarily represent the official views of the National Institutes of Health. J.Y. is also supported by an institutional match fund of a NIH pre-doctoral training grant in "Animal Models of Inflammation" (T32 Al074551) from The Pennsylvania State University.

\section{COMPLIANCE WITH ETHICS GUIDELINES}

Jie Yang, Luming Zhao, Ming $\mathrm{Xu}$, and $\mathrm{Na}$ Xiong declare that they have no conflict of interest. All institutional and national guidelines for the care and use of laboratory animals were followed.

\section{OPEN ACCESS}

This article is distributed under the terms of the Creative Commons Attribution 4.0 International License (http://creativecommons.org/ licenses/by/4.0/), which permits unrestricted use, distribution, and reproduction in any medium, provided you give appropriate credit to the original author(s) and the source, provide a link to the Creative Commons license, and indicate if changes were made.

\section{ABBREVIATIONS}

aLP, a-lymphoid precursor; CHILP, common helper-like innate lymphoid progenitor; CILP, common innate lymphoid progenitor; EILP, early ILC progenitor; Id2, inhibitor of DNA binding 2; IFNY, interferon $\mathrm{Y}$; IL-2, interleukin-2; ILCP, innate lymphoid progenitor; ILCs, innate lymphoid cells; LNs, lymph nodes; LTi, lymphoid tissue inducer; $\mathrm{MHCl}$, class I major histocompatibility complex; NCR, natural cytotoxicity receptor; NK, natural killer; PGD2, prostaglandin D2; PLZF, promyeloid leukemia zinc finger; SCID, severe combined immunodeficiency; Th, helper T; TNFa, tumor necrosis factor $\alpha$; TSLP, thymic stromal lymphopoietin.

\section{REFERENCES}

Almeida FF, Tenno M, Brzostek J, Li JL, Allies G, Hoeffel G, See P, $\mathrm{Ng}$ LG, Fehling HJ, Gascoigne NR et al (2015) Identification of a novel lymphoid population in the murine epidermis. Sci Rep 5:12554

Artis D, Spits H (2015) The biology of innate lymphoid cells. Nature 517:293-301

Austrup F, Vestweber D, Borges E, Lohning M, Brauer R, Herz U, Renz H, Hallmann R, Scheffold A, Radbruch A, Hamann A (1997) $\mathrm{P}$ - and E-selectin mediate recruitment of T-helper-1 but not T-helper-2 cells into inflammed tissues. Nature 385:81-83

Barnig C, Cernadas M, Dutile S, Liu X, Perrella MA, Kazani S, Wechsler ME, Israel E, Levy BD (2013) Lipoxin A4 regulates natural killer cell and type 2 innate lymphoid cell activation in asthma. Sci Transl Med 5:174ra126

Bartemes KR, Kephart GM, Fox SJ, Kita H (2014) Enhanced innate type 2 immune response in peripheral blood from patients with asthma. J Allergy Clin Immunol 134(671-678):e674 
Batista MD, Ho EL, Kuebler PJ, Milush JM, Lanier LL, Kallas EG, York VA, Chang D, Liao W, Unemori P et al (2013) Skewed distribution of natural killer cells in psoriasis skin lesions. Exp Dermatol 22:64-66

Bernink JH, Peters CP, Munneke M, te Velde AA, Meijer SL, Weijer $\mathrm{K}$, Hreggvidsdottir HS, Heinsbroek SE, Legrand N, Buskens CJ et al (2013) Human type 1 innate lymphoid cells accumulate in inflamed mucosal tissues. Nat Immunol 14:221-229

Bernink JH, Krabbendam L, Germar K, de Jong E, Gronke K, Kofoed-Nielsen M, Munneke JM, Hazenberg MD, Villaudy J, Buskens CJ et al (2015) Interleukin-12 and -23 control plasticity of CD127(+) Group 1 and Group 3 innate lymphoid cells in the intestinal lamina propria. Immunity 43:146-160

Biron CA, Nguyen KB, Pien GC, Cousens LP, Salazar-Mather TP (1999) Natural killer cells in antiviral defense: function and regulation by innate cytokines. Annu Rev Immunol 17:189-220

Buonocore S, Ahern PP, Uhlig HH, Ivanov II, Littman DR, Maloy KJ, Powrie F (2010) Innate lymphoid cells drive interleukin-23dependent innate intestinal pathology. Nature 464:1371-1375

Campbell DJ, Butcher EC (2002) Rapid acquisition of tissue-specific homing phenotypes by CD4(+) T cells activated in cutaneous or mucosal lymphoid tissues. J Exp Med 195:135-141

Campbell JJ, Haraldsen G, Pan J, Rottman J, Qin S, Ponath P, Andrew DP, Warnke R, Ruffing N, Kassam N et al (1999) The chemokine receptor CCR4 in vascular recognition by cutaneous but not intestinal memory T cells. Nature 400:776-780

Cella M, Otero K, Colonna M (2010) Expansion of human NK-22 cells with IL-7, IL-2, and IL-1beta reveals intrinsic functional plasticity. Proc Natl Acad Sci USA 107:10961-10966

Chang YJ, Kim HY, Albacker LA, Baumgarth N, McKenzie AN, Smith DE, Dekruyff RH, Umetsu DT (2011) Innate lymphoid cells mediate influenza-induced airway hyper-reactivity independently of adaptive immunity. Nat Immunol 12:631-638

Constantinides MG, McDonald BD, Verhoef PA, Bendelac A (2014) A committed precursor to innate lymphoid cells. Nature 508:397-401

Dadi S, Chhangawala S, Whitlock BM, Franklin RA, Luo CT, Oh SA, Toure A, Pritykin Y, Huse M, Leslie CS, Li MO (2016) Cancer immunosurveillance by tissue-resident innate lymphoid cells and innate-like T cells. Cell 164:365-377

Daussy C, Faure F, Mayol K, Viel S, Gasteiger G, Charrier E, Bienvenu J, Henry T, Debien E, Hasan UA et al (2014) T-bet and Eomes instruct the development of two distinct natural killer cell lineages in the liver and in the bone marrow. J Exp Med 211:563-577

De Togni P, Goellner J, Ruddle NH, Streeter PR, Fick A, Mariathasan S, Smith SC, Carlson R, Shornick LP, Strauss-Schoenberger J et al (1994) Abnormal development of peripheral lymphoid organs in mice deficient in lymphotoxin. Science 264:703-707

Doherty TA, Khorram N, Lund S, Mehta AK, Croft M, Broide DH (2013) Lung type 2 innate lymphoid cells express cysteinyl leukotriene receptor 1 , which regulates $\mathrm{TH} 2$ cytokine production. J Allergy Clin Immunol 132:205-213

Drake LY, lijima K, Kita H (2014) Group 2 innate lymphoid cells and CD4+ T cells cooperate to mediate type 2 immune response in mice. Allergy 69:1300-1307

Dudakov JA, Hanash AM, Jenq RR, Young LF, Ghosh A, Singer NV, West ML, Smith OM, Holland AM, Tsai JJ et al (2012) Interleukin-
22 drives endogenous thymic regeneration in mice. Science 336:91-95

Dyring-Andersen B, Geisler C, Agerbeck C, Lauritsen JP, Gudjonsdottir SD, Skov L, Bonefeld CM (2014) Increased number and frequency of group 3 innate lymphoid cells in nonlesional psoriatic skin. Br J Dermatol 170:609-616

Eberl G, Marmon S, Sunshine MJ, Rennert PD, Choi Y, Littman DR (2004) An essential function for the nuclear receptor RORy(t) in the generation of fetal lymphoid tissue inducer cells. Nat Immunol 5:64-73

Ebert LM, Meuter S, Moser B (2006) Homing and function of human skin $y \delta T$ cells and NK cells: relevance for tumor surveillance. J Immunol 176:4331-4336

Flier J, Boorsma DM, van Beek PJ, Nieboer C, Stoof TJ, Willemze R, Tensen CP (2001) Differential expression of CXCR3 targeting chemokines CXCL10, CXCL9, and CXCL11 in different types of skin inflammation. J Pathol 194:398-405

Fu Y, Yang J, Xiong N (2016) Cutting edge: skin CCR10+ CD8+ T cells support resident regulatory $\mathrm{T}$ cells $\mathrm{THROUGH}$ the $\mathrm{B7.2/}$ receptor axis to regulate local immune homeostasis and response. J Immunol 196:4859-4864

Fuchs A, Vermi W, Lee JS, Lonardi S, Gilfillan S, Newberry RD, Cella M, Colonna M (2013) Intraepithelial type 1 innate lymphoid cells are a unique subset of IL-12- and IL-15-responsive IFN- $\gamma$ producing cells. Immunity 38:769-781

Gasteiger G, Rudensky AY (2014) Interactions between innate and adaptive lymphocytes. Nat Rev Immunol 14:631-639

Gasteiger G, Fan X, Dikiy S, Lee SY, Rudensky AY (2015) Tissue residency of innate lymphoid cells in lymphoid and nonlymphoid organs. Science 350:981-985

Gauvreau GM, O'Byrne PM, Boulet LP, Wang Y, Cockcroft D, Bigler J, FitzGerald JM, Boedigheimer M, Davis BE, Dias C et al (2014) Effects of an anti-TSLP antibody on allergen-induced asthmatic responses. N Engl J Med 370:2102-2110

Gombert M, Dieu-Nosjean MC, Winterberg F, Bunemann E, Kubitza RC, Da Cunha L, Haahtela A, Lehtimaki S, Muller A, Rieker J et al (2005) CCL1-CCR8 interactions: an axis mediating the recruitment of $T$ cells and Langerhans-type dendritic cells to sites of atopic skin inflammation. J Immunol 174:5082-5091

Gordon SM, Chaix J, Rupp LJ, Wu J, Madera S, Sun JC, Lindsten T, Reiner SL (2012) The transcription factors T-bet and Eomes control key checkpoints of natural killer cell maturation. Immunity 36:55-67

Goto Y, Obata T, Kunisawa J, Sato S, Ivanov II, Lamichhane A, Takeyama N, Kamioka M, Sakamoto M, Matsuki T et al (2014) Innate lymphoid cells regulate intestinal epithelial cell glycosylation. Science 345:1254009

Gudjonsson JE, Ding J, Johnston A, Tejasvi T, Guzman AM, Nair RP, Voorhees JJ, Abecasis GR, Elder JT (2010) Assessment of the psoriatic transcriptome in a large sample: additional regulated genes and comparisons with in vitro models. J Invest Dermatol 130:1829-1840

Guo X, Liang Y, Zhang Y, Lasorella A, Kee BL, Fu YX (2015) Innate lymphoid cells control early colonization resistance against intestinal pathogens through ID2-dependent regulation of the microbiota. Immunity 42:731-743 
Gury-BenAri M, Thaiss CA, Serafini N, Winter DR, Giladi A, LaraAstiaso D, Levy M, Salame TM, Weiner A, David E et al (2016) The spectrum and regulatory landscape of intestinal innate lymphoid cells are shaped by the microbiome. Cell 166(1231-1246):e1213

Halim TY, MacLaren A, Romanish MT, Gold MJ, McNagny KM, Takei F (2012) Retinoic-acid-receptor-related orphan nuclear receptor alpha is required for natural helper cell development and allergic inflammation. Immunity 37:463-474

Halim TY, Steer CA, Matha L, Gold MJ, Martinez-Gonzalez I, McNagny KM, McKenzie AN, Takei F (2014) Group 2 innate lymphoid cells are critical for the initiation of adaptive T helper 2 cell-mediated allergic lung inflammation. Immunity 40:425-435

Hambly N, Nair P (2014) Monoclonal antibodies for the treatment of refractory asthma. Curr Opin Pulm Med 20:87-94

Hams E, Locksley RM, McKenzie AN, Fallon PG (2013) Cutting edge: IL-25 elicits innate lymphoid type 2 and type II NKT cells that regulate obesity in mice. J Immunol 191:5349-5353

Hams E, Armstrong ME, Barlow JL, Saunders SP, Schwartz C, Cooke G, Fahy RJ, Crotty TB, Hirani N, Flynn RJ et al (2014) IL25 and type 2 innate lymphoid cells induce pulmonary fibrosis. Proc Natl Acad Sci USA 111:367-372

Hepworth MR, Monticelli LA, Fung TC, Ziegler CG, Grunberg S, Sinha R, Mantegazza AR, Ma HL, Crawford A, Angelosanto JM et al (2013) Innate lymphoid cells regulate CD4+ T-cell responses to intestinal commensal bacteria. Nature 498:113-117

Herberman RB, Nunn ME, Holden HT, Lavrin DH (1975a) Natural cytotoxic reactivity of mouse lymphoid cells against syngeneic and allogeneic tumors. II. Characterization of effector cells. Int $\mathrm{J}$ Cancer 16:230-239

Herberman RB, Nunn ME, Lavrin DH (1975b) Natural cytotoxic reactivity of mouse lymphoid cells against syngeneic acid allogeneic tumors. I. Distribution of reactivity and specificity. Int J Cancer 16:216-229

Homey B, Wang W, Soto H, Buchanan ME, Wiesenborn A, Catron D, Muller A, McClanahan TK, Dieu-Nosjean MC, Orozco R et al (2000) Cutting edge: the orphan chemokine receptor $G$ proteincoupled receptor-2 (GPR-2, CCR10) binds the skin-associated chemokine CCL27 (CTACK/ALP/ILC). J Immunol 164:3465-3470

Homey B, Alenius $H$, Muller A, Soto $H$, Bowman EP, Yuan W, McEvoy L, Lauerma Al, Assmann T, Bunemann E et al (2002) CCL27-CCR10 interactions regulate T cell-mediated skin inflammation. Nat Med 8:157-165

Hoyler T, Klose CS, Souabni A, Turqueti-Neves A, Pfeifer D, Rawlins EL, Voehringer D, Busslinger M, Diefenbach A (2012) The transcription factor GATA-3 controls cell fate and maintenance of type 2 innate lymphoid cells. Immunity 37:634-648

Imai Y, Yasuda K, Sakaguchi Y, Haneda T, Mizutani H, Yoshimoto T, Nakanishi K, Yamanishi K (2013) Skin-specific expression of IL33 activates group 2 innate lymphoid cells and elicits atopic dermatitis-like inflammation in mice. Proc Natl Acad Sci USA 110:13921-13926

Ishizuka IE, Constantinides MG, Gudjonson H, Bendelac A (2016) The innate lymphoid cell precursor. Annu Rev Immunol 34:299316

Kanda N, Koike S, Watanabe S (2005) IL-17 suppresses TNF-alphainduced CCL27 production through induction of COX-2 in human keratinocytes. J Allergy Clin Immunol 116:1144-1150
Kantele A, Zivny J, Hakkinen M, Elson CO, Mestecky J (1999) Differential homing commitments of antigen-specific Tcells after oral or parenteral immunization in humans. J Immunol 162:5173-5177

Karakawa M, Komine M, Hanakawa Y, Tsuda H, Sayama K, Tamaki K, Ohtsuki M (2014) CCL27 is downregulated by interferon y via epidermal growth factor receptor in normal human epidermal keratinocytes. J Cell Physiol 229(12):1935-1945

Kiessling R, Klein E, Pross H, Wigzell H (1975a) "Natural" killer cells in the mouse. II. Cytotoxic cells with specificity for mouse Moloney leukemia cells. Characteristics of the killer cell. Eur J Immunol 5:117-121

Kiessling R, Klein E, Wigzell H (1975b) "Natural" killer cells in the mouse. I. Cytotoxic cells with specificity for mouse Moloney leukemia cells. Specificity and distribution according to genotype. Eur J Immunol 5:112-117

Kim BS, Siracusa MC, Saenz SA, Noti M, Monticelli LA, Sonnenberg GF, Hepworth MR, Van Voorhees AS, Comeau MR, Artis D (2013) TSLP elicits IL-33-independent innate lymphoid cell responses to promote skin inflammation. Sci Transl Med 5:170ra116

Kim BS, Wang K, Siracusa MC, Saenz SA, Brestoff JR, Monticelli LA, Noti M, Tait Wojno ED, Fung TC, Kubo M, Artis D (2014a) Basophils promote innate lymphoid cell responses in inflamed skin. J Immunol 193:3717-3725

Kim HY, Lee HJ, Chang YJ, Pichavant M, Shore SA, Fitzgerald KA, Iwakura Y, Israel E, Bolger K, Faul J et al (2014b) Interleukin-17producing innate lymphoid cells and the NLRP3 inflammasome facilitate obesity-associated airway hyperreactivity. Nat Med 20:54-61

Kim MH, Taparowsky EJ, Kim CH (2015) Retinoic acid differentially regulates the migration of innate lymphoid cell subsets to the gut. Immunity 43:107-119

Kirchberger S, Royston DJ, Boulard O, Thornton E, Franchini F, Szabady RL, Harrison O, Powrie F (2013) Innate lymphoid cells sustain colon cancer through production of interleukin-22 in a mouse model. J Exp Med 210:917-931

Klose CS, Kiss EA, Schwierzeck V, Ebert K, Hoyler T, d'Hargues Y, Goppert N, Croxford AL, Waisman A, Tanriver Y, Diefenbach A (2013) A T-bet gradient controls the fate and function of CCR6RORyt+ innate lymphoid cells. Nature 494:261-265

Klose CS, Flach M, Mohle L, Rogell L, Hoyler T, Ebert K, Fabiunke C, Pfeifer D, Sexl V, Fonseca-Pereira D et al (2014) Differentiation of type 1 ILCs from a common progenitor to all helper-like innate lymphoid cell lineages. Cell 157:340-356

Kruglov AA, Grivennikov SI, Kuprash DV, Winsauer C, Prepens S, Seleznik GM, Eberl G, Littman DR, Heikenwalder M, Tumanov AV, Nedospasov SA (2013) Nonredundant function of soluble LTalpha3 produced by innate lymphoid cells in intestinal homeostasis. Science 342:1243-1246

Leung DY (2013) New insights into atopic dermatitis: role of skin barrier and immune dysregulation. Allergol Int 62:151-161

Li Z, Hodgkinson T, Gothard EJ, Boroumand S, Lamb R, Cummins I, Narang P, Sawtell A, Coles J, Leonov G et al (2016) Epidermal Notch1 recruits $\mathrm{RORY}^{+}+$group 3 innate lymphoid cells to orchestrate normal skin repair. Nat Commun 7:11394

Lonsdorf AS, Hwang ST, Enk AH (2009) Chemokine receptors in T-cell-mediated diseases of the skin. J Invest Dermatol 129:2552-2566 
Luci C, Reynders A, Ivanov II, Cognet C, Chiche L, Chasson L, Hardwigsen J, Anguiano E, Banchereau J, Chaussabel D et al (2009) Influence of the transcription factor RORyt on the development of NKp46+ cell populations in gut and skin. Nat Immunol 10:75-82

Masopust D, Schenkel JM (2013) The integration of T cell migration, differentiation and function. Nat Rev Immunol 13:309-320

McHedlidze T, Waldner M, Zopf S, Walker J, Rankin AL, Schuchmann M, Voehringer D, McKenzie AN, Neurath MF, Pflanz S, Wirtz S (2013) Interleukin-33-dependent innate lymphoid cells mediate hepatic fibrosis. Immunity 39:357-371

McKenzie AN, Spits H, Eberl G (2014) Innate lymphoid cells in inflammation and immunity. Immunity 41:366-374

Mebius RE, Rennert P, Weissman IL (1997) Developing lymph nodes collect CD4+CD3- LTbeta+ cells that can differentiate to APC, NK cells, and follicular cells but not T or B cells. Immunity 7:493-504

Moed H, Boorsma DM, Tensen CP, Flier J, Jonker MJ, Stoof TJ, von Blomberg BM, Bruynzeel DP, Scheper RJ, Rustemeyer T, Gibbs $S$ (2004) Increased CCL27-CCR10 expression in allergic contact dermatitis: implications for local skin memory. J Pathol 204:39-46

Moffatt MF, Gut IG, Demenais F, Strachan DP, Bouzigon E, Heath S, von Mutius E, Farrall M, Lathrop M, Cookson WO (2010) A largescale, consortium-based genomewide association study of asthma. N Engl J Med 363:1211-1221

Molofsky AB, Nussbaum JC, Liang HE, Van Dyken SJ, Cheng LE, Mohapatra A, Chawla A, Locksley RM (2013) Innate lymphoid type 2 cells sustain visceral adipose tissue eosinophils and alternatively activated macrophages. J Exp Med 210:535-549

Monticelli LA, Sonnenberg GF, Abt MC, Alenghat T, Ziegler CG, Doering TA, Angelosanto JM, Laidlaw BJ, Yang CY, Sathaliyawala $T$ et al (2011) Innate lymphoid cells promote lung-tissue homeostasis after infection with influenza virus. Nat Immunol 12:1045-1054

Mora JR, von Andrian UH (2006) T-cell homing specificity and plasticity: new concepts and future challenges. Trends Immunol 27:235-243

Mora JR, Bono MR, Manjunath N, Weninger W, Cavanagh LL, Rosemblatt M, Von Andrian UH (2003) Selective imprinting of gut-homing $T$ cells by Peyer's patch dendritic cells. Nature 424:88-93

Mora JR, Cheng G, Picarella D, Briskin M, Buchanan N, von Andrian UH (2005) Reciprocal and dynamic control of CD8 T cell homing by dendritic cells from skin- and gut-associated lymphoid tissues. J Exp Med 201:303-316

Morales J, Homey B, Vicari AP, Hudak S, Oldham E, Hedrick J, Orozco R, Copeland NG, Jenkins NA, McEvoy LM, Zlotnik A (1999) CTACK, a skin-associated chemokine that preferentially attracts skin-homing memory T cells. Proc Natl Acad Sci USA 96:14470-14475

Moro K, Kabata H, Tanabe M, Koga S, Takeno N, Mochizuki M, Fukunaga K, Asano K, Betsuyaku T, Koyasu S (2016) Interferon and IL-27 antagonize the function of group 2 innate lymphoid cells and type 2 innate immune responses. Nat Immunol 17:76-86

Mortha A, Chudnovskiy A, Hashimoto D, Bogunovic M, Spencer SP, Belkaid Y, Merad M (2014) Microbiota-dependent crosstalk between macrophages and ILC3 promotes intestinal homeostasis. Science 343:1249288

Neill DR, Wong SH, Bellosi A, Flynn RJ, Daly M, Langford TK, Bucks C, Kane CM, Fallon PG, Pannell R et al (2010) Nuocytes represent a new innate effector leukocyte that mediates type-2 immunity. Nature 464:1367-1370

Nussbaum JC, Van Dyken SJ, von Moltke J, Cheng LE, Mohapatra A, Molofsky AB, Thornton EE, Krummel MF, Chawla A, Liang HE, Locksley RM (2013) Type 2 innate lymphoid cells control eosinophil homeostasis. Nature 502:245-248

Oliphant CJ, Hwang YY, Walker JA, Salimi M, Wong SH, Brewer JM, Englezakis A, Barlow JL, Hams E, Scanlon ST et al (2014) MHCII-mediated dialog between group 2 innate lymphoid cells and CD4(+) T cells potentiates type 2 immunity and promotes parasitic helminth expulsion. Immunity 41:283-295

O'Sullivan TE, Rapp M, Fan X, Weizman OE, Bhardwaj P, Adams NM, Walzer T, Dannenberg AJ, Sun JC (2016) Adipose-resident group 1 Innate lymphoid cells promote obesity-associated insulin resistance. Immunity 45:428-441

Pantelyushin S, Haak S, Ingold B, Kulig P, Heppner FL, Navarini AA, Becher B (2012) Roryt+ innate lymphocytes and $y \delta$ T cells initiate psoriasiform plaque formation in mice. J Clin Invest 122:22522256

Peng $H$, Jiang $X$, Chen $Y$, Sojka DK, Wei $H$, Gao $X$, Sun $R$, Yokoyama WM, Tian Z (2013) Liver-resident NK cells confer adaptive immunity in skin-contact inflammation. J Clin Invest 123:1444-1456

Perry JS, Han S, Xu Q, Herman ML, Kennedy LB, Csako G, Bielekova B (2012) Inhibition of LTi cell development by CD25 blockade is associated with decreased intrathecal inflammation in multiple sclerosis. Sci Transl Med 4:145ra106

Picker LJ, Treer JR, Ferguson-Darnell B, Collins PA, Bergstresser PR, Terstappen LW (1993) Control of lymphocyte recirculation in man. II. Differential regulation of the cutaneous lymphocyteassociated antigen, a tissue-selective homing receptor for skinhoming T cells. J Immunol 150:1122-1136

Pivarcsi A, Gombert M, Dieu-Nosjean MC, Lauerma A, Kubitza R, Meller S, Rieker J, Muller A, Da Cunha L, Haahtela A et al (2004) CC chemokine ligand 18, an atopic dermatitis-associated and dendritic cell-derived chemokine, is regulated by staphylococcal products and allergen exposure. J Immunol 173:5810-5817

Powell N, Walker AW, Stolarczyk E, Canavan JB, Gokmen MR, Marks E, Jackson I, Hashim A, Curtis MA, Jenner RG et al (2012) The transcription factor T-bet regulates intestinal inflammation mediated by interleukin-7 receptor+ innate lymphoid cells. Immunity 37:674-684

Price AE, Liang HE, Sullivan BM, Reinhardt RL, Eisley CJ, Erle DJ, Locksley RM (2010) Systemically dispersed innate IL-13-expressing cells in type 2 immunity. Proc Natl Acad Sci USA 107:11489-11494

Pulendran B, Artis D (2012) New paradigms in type 2 immunity. Science 337:431-435

Qiu J, Guo X, Chen ZM, He L, Sonnenberg GF, Artis D, Fu YX, Zhou L (2013) Group 3 innate lymphoid cells inhibit T-cell-mediated intestinal inflammation through aryl hydrocarbon receptor signaling and regulation of microflora. Immunity 39:386-399 
Quaranta M, Knapp B, Garzorz N, Mattii M, Pullabhatla V, Pennino D, Andres C, Traidl-Hoffmann C, Cavani A, Theis FJ et al (2014). Intraindividual genome expression analysis reveals a specific molecular signature of psoriasis and eczema. Sci Transl Med 6:244ra290

Rak GD, Osborne LC, Siracusa MC, Kim BS, Wang K, Bayat A, Artis D, Volk SW (2016) IL-33-dependent group 2 innate lymphoid cells promote cutaneous wound healing. J Invest Dermatol 136:487-496

Rankin LC, Groom JR, Chopin M, Herold MJ, Walker JA, Mielke LA, McKenzie AN, Carotta S, Nutt SL, Belz GT (2013) The transcription factor T-bet is essential for the development of $\mathrm{NKp} 46+$ innate lymphocytes via the Notch pathway. Nat Immunol 14:389-395

Reiss Y, Proudfoot AE, Power CA, Campbell JJ, Butcher EC (2001) CC chemokine receptor (CCR)4 and the CCR10 ligand cutaneous $\mathrm{T}$ cell-attracting chemokine (CTACK) in lymphocyte trafficking to inflamed skin. J Exp Med 194:1541-1547

Riis JL, Johansen C, Vestergaard C, Bech R, Kragballe K, Iversen L (2011a) Kinetics and differential expression of the skin-related chemokines CCL27 and CCL17 in psoriasis, atopic dermatitis and allergic contact dermatitis. Exp Dermatol 20:789-794

Riis JL, Johansen C, Vestergaard C, Otkjaer K, Kragballe K, Iversen $L$ (2011b) CCL27 expression is regulated by both p38 MAPK and IKK $\beta$ signalling pathways. Cytokine 56:699-707

Roediger B, Kyle R, Yip KH, Sumaria N, Guy TV, Kim BS, Mitchell AJ, Tay SS, Jain R, Forbes-Blom E et al (2013) Cutaneous immunosurveillance and regulation of inflammation by group 2 innate lymphoid cells. Nat Immunol 14:564-573

Rott LS, Rose JR, Bass D, Williams MB, Greenberg HB, Butcher EC (1997) Expression of mucosal homing receptor alpha4beta7 by circulating CD4+ cells with memory for intestinal rotavirus. J Clin Invest 100:1204-1208

Salimi M, Barlow JL, Saunders SP, Xue L, Gutowska-Owsiak D, Wang X, Huang LC, Johnson D, Scanlon ST, McKenzie AN et al (2013) A role for IL-25 and IL-33-driven type-2 innate lymphoid cells in atopic dermatitis. J Exp Med 210:2939-2950

Sawa S, Lochner M, Satoh-Takayama N, Dulauroy S, Berard M, Kleinschek M, Cua D, Di Santo JP, Eberl G (2011) RORyt+ innate lymphoid cells regulate intestinal homeostasis by integrating negative signals from the symbiotic microbiota. Nat Immunol 12:320-326

Scoville SD, Mundy-Bosse BL, Zhang MH, Chen L, Zhang X, Keller KA, Hughes T, Chen L, Cheng S, Bergin SM et al (2016) A progenitor cell expressing transcription factor RORyt generates all human innate lymphoid cell subsets. Immunity 44:1140-1150

Seillet C, Rankin LC, Groom JR, Mielke LA, Tellier J, Chopin M, Huntington ND, Belz GT, Carotta S (2014) Nfil3 is required for the development of all innate lymphoid cell subsets. J Exp Med 211:1733-1740

Serafini N, Vosshenrich CA, Di Santo JP (2015) Transcriptional regulation of innate lymphoid cell fate. Nat Rev Immunol 15:415-428

Sigmundsdottir H, Butcher EC (2008) Environmental cues, dendritic cells and the programming of tissue-selective lymphocyte trafficking. Nat Immunol 9:981-987

Sigmundsdottir H, Pan J, Debes GF, Alt C, Habtezion A, Soler D, Butcher EC (2007) DCs metabolize sunlight-induced vitamin D3 to 'program' T cell attraction to the epidermal chemokine CCL27. Nat Immunol 8:285-293

Sojka DK, Plougastel-Douglas B, Yang L, Pak-Wittel MA, Artyomov MN, Ivanova Y, Zhong C, Chase JM, Rothman PB, Yu J et al (2014) Tissue-resident natural killer (NK) cells are cell lineages distinct from thymic and conventional splenic NK cells. eLife 3: e01659

Solt LA, Kumar N, Nuhant P, Wang Y, Lauer JL, Liu J, Istrate MA, Kamenecka TM, Roush WR, Vidovic D et al (2011) Suppression of TH17 differentiation and autoimmunity by a synthetic ROR ligand. Nature 472:491-494

Sonnenberg GF, Fouser LA, Artis D (2011) Border patrol: regulation of immunity, inflammation and tissue homeostasis at barrier surfaces by IL-22. Nat Immunol 12:383-390

Sonnenberg GF, Monticelli LA, Alenghat T, Fung TC, Hutnick NA, Kunisawa J, Shibata N, Grunberg S, Sinha R, Zahm AM et al (2012) Innate lymphoid cells promote anatomical containment of lymphoid-resident commensal bacteria. Science 336:1321-1325

Spencer SP, Wilhelm C, Yang Q, Hall JA, Bouladoux N, Boyd A, Nutman TB, Urban JF Jr, Wang J, Ramalingam TR et al (2014) Adaptation of innate lymphoid cells to a micronutrient deficiency promotes type 2 barrier immunity. Science 343:432-437

Spits H, Artis D, Colonna M, Diefenbach A, Di Santo JP, Eberl G, Koyasu S, Locksley RM, McKenzie AN, Mebius RE et al (2013) Innate lymphoid cells-a proposal for uniform nomenclature. Nat Rev Immunol 13:145-149

Stanya KJ, Jacobi D, Liu S, Bhargava P, Dai L, Gangl MR, Inouye K, Barlow JL, Ji Y, Mizgerd JP et al (2013) Direct control of hepatic glucose production by interleukin-13 in mice. J Clin Invest 123:261-271

Taube C, Tertilt C, Gyulveszi G, Dehzad N, Kreymborg K, Schneeweiss K, Michel E, Reuter S, Renauld JC, Arnold-Schild D et al (2011) IL-22 is produced by innate lymphoid cells and limits inflammation in allergic airway disease. PLoS ONE 6: e21799

Teunissen MB, Munneke JM, Bernink JH, Spuls PI, Res PC, Te Velde A, Cheuk S, Brouwer MW, Menting SP, Eidsmo L et al (2014) Composition of innate lymphoid cell subsets in the human skin: enrichment of NCR ILC3 in lesional skin and blood of psoriasis patients. J Invest Dermatol 134(9):2351-2360

van de Pavert SA, Olivier BJ, Goverse G, Vondenhoff MF, Greuter M, Beke P, Kusser K, Hopken UE, Lipp M, Niederreither K et al (2009) Chemokine CXCL13 is essential for lymph node initiation and is induced by retinoic acid and neuronal stimulation. Nat Immunol 10:1193-1199

Vely F, Barlogis V, Vallentin B, Neven B, Piperoglou C, Ebbo M, Perchet T, Petit M, Yessaad N, Touzot F et al (2016) Evidence of innate lymphoid cell redundancy in humans. Nat Immunol 17:1291-1299

Vestergaard C, Johansen C, Christensen U, Just H, Hohwy T, Deleuran M (2004) TARC augments TNF-alpha-induced CTACK production in keratinocytes. Exp Dermatol 13:551-557

Villanova F, Flutter B, Tosi I, Grys K, Sreeneebus H, Perera GK, Chapman A, Smith CH, Di Meglio P, Nestle FO (2014) Characterization of innate lymphoid cells in human skin and blood demonstrates increase of NKp44+ ILC3 in psoriasis. J Invest Dermatol 134:984-991 
Vivier E, Raulet DH, Moretta A, Caligiuri MA, Zitvogel L, Lanier LL, Yokoyama WM, Ugolini S (2011) Innate or adaptive immunity? The example of natural killer cells. Science 331:44-49

Vivier E, Ugolini S, Blaise D, Chabannon C, Brossay L (2012) Targeting natural killer cells and natural killer T cells in cancer. Nat Rev Immunol 12:239-252

Vonarbourg C, Mortha A, Bui VL, Hernandez PP, Kiss EA, Hoyler T, Flach M, Bengsch B, Thimme R, Holscher C et al (2010) Regulated expression of nuclear receptor RORyt confers distinct functional fates to NK cell receptor-expressing RORyt(+) innate lymphocytes. Immunity 33:736-751

Walker JA, Barlow JL, McKenzie AN (2013) Innate lymphoid cellshow did we miss them? Nat Rev Immunol 13:75-87

Weninger W, Ulfman LH, Cheng G, Souchkova N, Quackenbush EJ, Lowe JB, von Andrian UH (2000) Specialized contributions by alpha(1,3)-fucosyltransferase-IV and FucT-VII during leukocyte rolling in dermal microvessels. Immunity 12:665-676

Withers DR, Hepworth MR, Wang X, Mackley EC, Halford EE, Dutton EE, Marriott CL, Brucklacher-Waldert V, Veldhoen $M$, Kelsen J et al (2016) Transient inhibition of ROR-yt therapeutically limits intestinal inflammation by reducing $\mathrm{TH} 17$ cells and preserving group 3 innate lymphoid cells. Nat Med 22:319-323

Xia M, Hu S, Fu Y, Jin W, Yi Q, Matsui Y, Yang J, McDowell MA, Sarkar S, Kalia V, Xiong N (2014) CCR10 regulates balanced maintenance and function of resident regulatory and effector $\mathrm{T}$ cells to promote immune homeostasis in the skin. J Allergy Clin Immunol 134(634-644):e610

Xiong N, Fu Y, Hu S, Xia M, Yang J (2012) CCR10 and its ligands in regulation of epithelial immunity and diseases. Protein Cell 3:571-580
Xue L, Salimi M, Panse I, Mjosberg JM, McKenzie AN, Spits H, Klenerman P, Ogg G (2014) Prostaglandin D2 activates group 2 innate lymphoid cells through chemoattractant receptor-homologous molecule expressed on TH2 cells. J Allergy Clin Immunol 133:1184-1194

Yagi R, Zhong C, Northrup DL, Yu F, Bouladoux N, Spencer S, Hu G, Barron L, Sharma S, Nakayama T et al (2014) The transcription factor GATA3 is critical for the development of all IL-7Ralphaexpressing innate lymphoid cells. Immunity 40:378-388

Yang Q, Bhandoola A (2016) The development of adult innate lymphoid cells. Curr Opin Immunol 39:114-120

Yang Q, Li F, Harly C, Xing S, Ye L, Xia X, Wang H, Wang X, Yu S, Zhou $X$ et al (2015) TCF-1 upregulation identifies early innate lymphoid progenitors in the bone marrow. Nat Immunol 16:10441050

Yang J, Hu S, Zhao L, Kaplan DH, Perdew GH, Xiong N (2016) Selective programming of $\mathrm{CCR} 10(+)$ innate lymphoid cells in skin-draining lymph nodes for cutaneous homeostatic regulation. Nat Immunol 17:48-56

Yu X, Wang Y, Deng M, Li Y, Ruhn KA, Zhang CC, Hooper LV (2014) The basic leucine zipper transcription factor NFIL3 directs the development of a common innate lymphoid cell precursor. eLife. doi:10.7554/eLife.04406

Zheng Y, Valdez PA, Danilenko DM, Hu Y, Sa SM, Gong Q, Abbas AR, Modrusan Z, Ghilardi N, de Sauvage FJ, Ouyang W (2008) Interleukin-22 mediates early host defense against attaching and effacing bacterial pathogens. Nat Med 14:282-289

Zook EC, Kee BL (2016) Development of innate lymphoid cells. Nat Immunol 17:775-782 